\title{
Monitoring of soil organic carbon and nitrogen stocks in different land use under surface water erosion in a semi-arid drainage basin of Iran
}

\section{*KAZEM NOSRATI, FOROUZAN AHMADI}

\author{
Department of Physical Geography, Faculty of Earth Sciences, Shahid Beheshti University, G. C., 1983963113 \\ Tehran, Iran
}

Keywords: SOC stock; SN stock; Land use; Surface waterr erosion; Taleghani catchment

\begin{abstract}
Soil organic carbon (SOC) and soil nitrogen (SN) are the principal components in soil quality assessment, and in mitigation the global greenhouse effect. In Iran, little information exists on the stocks of SOC and SN. SOC and SN stocks are a function of the SOC and SN concentrations and the bulk density of the soil that are prone to changes under land use types and soil erosion. The objective of this study was to evaluate SOC and SN stock in different land use types under surface erosion at catchment scale. In view of this, bulk density, SOC and SN concentration were measured in 39 different sampling sites of three main groups of land use affected by surface erosion namely, rangeland, crop field, and forest land at Taleghani catchment, Khoramabad, Iran. The results showed that SOC and SN stock under all land use types was significantly different $(\mathrm{P}<0.01)$. SOC and SN stocks were greatest in the forest land use. The SOC stock for the $30 \mathrm{~cm}$ soil layer in different land uses varied in order forest $\left(66.9 \mathrm{Mg} \mathrm{ha}^{-1}\right)>\operatorname{rangeland}\left(63.3 \mathrm{Mg} \mathrm{ha}^{-1}\right)>$ crop field $\left(47.2 \mathrm{Mg} \mathrm{ha}^{-1}\right.$; $\mathrm{P}<0.01)$. Also the $\mathrm{SN}$ stock had the same trend in all studied land uses. These results can be useful as a scientific basis for selecting the proper soil management as a simple and low-cost approach to mitigate the SOC and SN loss. @JASEM
\end{abstract}

DOI: http:/ / dx.doi.org/10.4314/jasem.v17i2.6

Soil erosion is a global environmental problem, which refers to the displacement of soil from the place of its formation by causative agents, including raindrops, runoff, wind and gravity (Lal, 2003). Water erosion as the principal component of total soil erosion is the removal of a thin layer of particulate matter across the land surface and truncating the A horizon, which can redistribute considerable amounts of soil, soil organic carbon (SOC) and soil nitrogen (SN). SOC and SN are important components of the terrestrial $\mathrm{C}$ and $\mathrm{N}$ pool and are important indicators of soil fertility and productivity. Soil erosion alters the fluxes of SOC and $\mathrm{SN}$ because removes and redistributes the $\mathrm{C}$ - and $\mathrm{N}$ enriched sediment and accelerates the process of mineralization (e.g., $\mathrm{C}$ emissions). Each process of soil erosion including detachment, transport, distribution, and deposition affects $\mathrm{C}$ and $\mathrm{N}$ dynamics. The amount of $\mathrm{C}$ and $\mathrm{N}$ removed by erosion depends on the magnitude of sediment removal. Surface cover conditions, soil properties, and degree of soil organic matter decomposition are some of the factors that affect the magnitude of $\mathrm{C}$ removal (Blanco \& Lal, 2008). Therefore, increase of SOC and SN loss by land use changes and soil erosion decrease SOM/SOC and consequently reduce the satisfactory level of SOC and TN that is necessary for sustainable agroecosystems. The net release of $\mathrm{C}$ to the atmosphere is in the range of $0.37-1 \mathrm{pg}$ year $^{-1}$ (Lal et al., 2004) versus the sink is in the range of 0.56 - 1 pg year ${ }^{-1}$ (Smith et al., 2005). The last estimations reported by Van Oost et al. (2007) point to an erosion-induced sink of atmospheric C equivalent to approximately $26 \%$ of the $\mathrm{C}$ transported by erosion. Therefore knowledge of soil organic carbon and nitrogen stocks are important to reduce $\mathrm{CO}_{2}$ emission to the atmosphere.

In a review, Don et al. (2007) concluded that SOC stocks at the clay rich site with Vertisols were almost twice as high (86 t ha- $\mathrm{th}^{-1}$ in $60 \mathrm{~cm}$ depth) as at the sandy site with Arenosols $\left(48 \mathrm{t} \mathrm{ha}^{-1}\right)$. John et al. (2005) have shown that total SOC stocks down to a depth of $60 \mathrm{~cm}$ and including the humus layer were larger at the spruce site $\left(10.3 \mathrm{~kg} \mathrm{~m}^{-2}\right)$ as compared with the grassland, wheat and maize ( 7 to $8 \mathrm{~kg} \mathrm{~m}^{-2}$ ). However, SOC stocks in the mineral soil were smaller in the forest soil than in the agricultural soils. Grimm et al. (2008) estimate SOC stocks in the upper $30 \mathrm{~cm}$ on Barro Colorado Island ranged between 38 and $116 \mathrm{Mg} \mathrm{ha}{ }^{-1}$, with lowest stocks on midslope and highest on toeslope positions. Wang et al. (2010) found that SOC stock is as large as $2.67 \times 10^{3} \mathrm{t}(0$ $30 \mathrm{~cm}$ ) in Yangjuangou watershed, China. Leifeld et al. (2005) reported that about $16 \%$ of the SOC stock in Swiss land area has been lost historically due to peatland cultivation, urbanization, and deforestation.

Accelerated soil erosion is also a serious problem in Iran, leading to soil degradation and consequently decreasing SOC and SN stocks. SOC and SN stocks are a function of the SOC and SN concentration and the bulk density of the soil. All mentioned variables are prone to changes and are influenced by land use changes. Consequently, the types of land use are 
important factors controlling SOC and SN stocks. In Iran, also little information exists on the stocks of SOC and SN. Therefore, the objective of this study was to evaluate SOC and SN stock in different land use types under surface water erosion at catchment scale.

\section{MATERIALS AND METHODS}

Description of the catchment: The study was conducted in the Taleghani catchment $\left(33^{\circ} 42^{\prime}\right.$ to 33 $44^{\prime} \mathrm{N}$ and $47^{\circ} 39^{\prime}$ to $47^{\circ} 44^{\prime} \mathrm{E}$ ) which is part of the Kashkan Drainage Basin, Karkheh Drainage Basin, in the $20 \mathrm{~km}$ Northern of Koohdasht, Lorestan Province, Iran (Fig. 1). The drainage area of the Taleghani catchment is $25 \mathrm{~km}^{2}$. Taleghani catchment has a mountainous topography, with a minimum and maximum height $1240 \mathrm{~m}$ and $2320 \mathrm{~m}$ above the sea level.

The long-term (1975-2005) mean annual precipitation is $450 \mathrm{~mm}$ in the region that most rainfall occurs in late autumn and winter. Geological formations including Amiran, Taleh Zang and Quaternary Formations are exposed at the surface in the drainage basin.

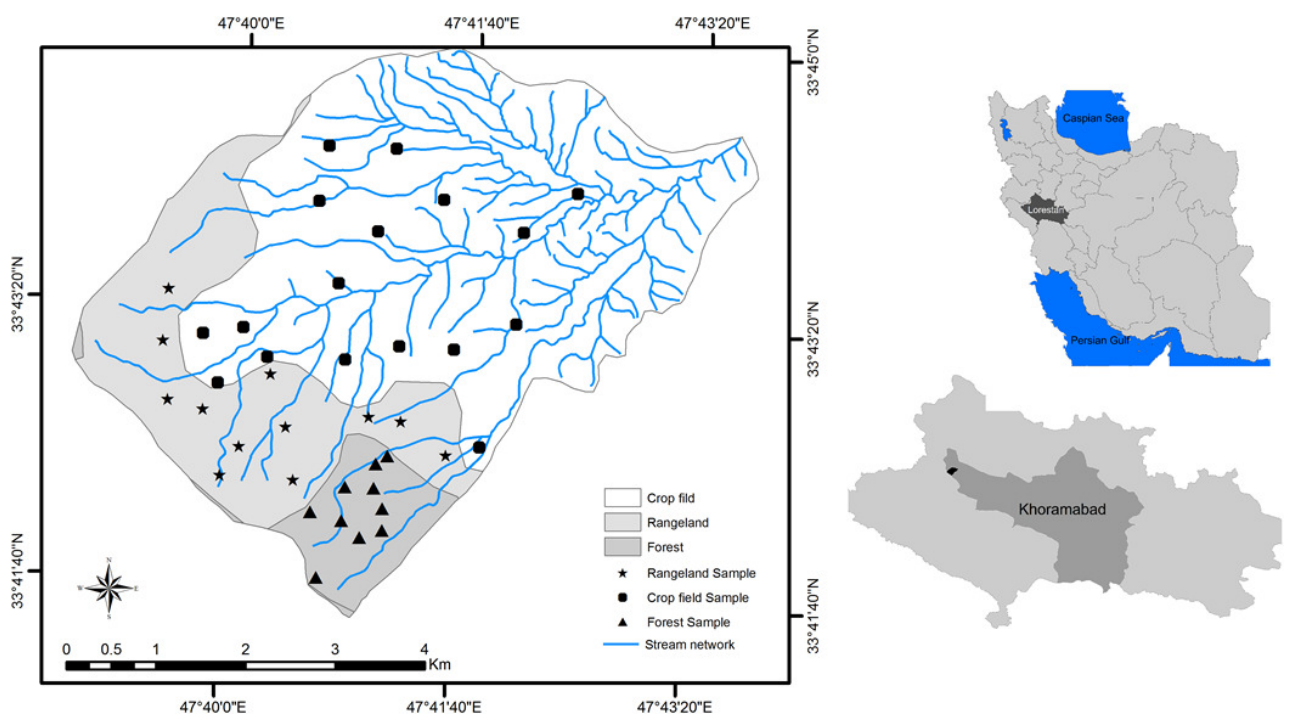

Fig. 1 Location map of the Taleghani catchment and sampling sites used in this analysis.

Sampling and data collection: Soil sampling sites were classified in three main land use types affected by surface water erosion; rangeland, forest and crop field and 12, 10 and 17 representative samples were collected from these sites at different locations within the Taleghani catchment, respectively (Fig. 1). Sampling sites were selected so that similar landform (slope, aspect and elevation) or uniform topographic positions were selected in all sites. The samples were collected by taking a representative sample of the top soil layer $(0-30 \mathrm{~cm})$ in $10 \mathrm{~cm}$ intervals. In each sampling site 5 sub-samples were collected over an area of approximately $100 \mathrm{~m}^{2}$ which were mixed into a single composite sample.

Soil bulk density was measured on $6 \mathrm{~cm}$ long and $6 \mathrm{~cm}$ diameter stainless steel cores (Blake \& Hartge, 1986). Samples were air-dried and sieved $(<2 \mathrm{~mm})$ for organic $\mathrm{C}$ and $\mathrm{N}$ concentrations measurement. The organic $\mathrm{C}$ content was measured by the WalkleyBlack method (Skjemstad \& Baldock, 2008). The nitrogen concentration was measured by the Kjeldahl method using Kjeldahl distillation unit FOSS Model 2100 (Rutherford et al, 2008). The SOC and SN stocks were calculated based on the following formula:

$$
S O C S / S N S=\sum_{i=1}^{n}\left(1-\theta_{i}\right) \times \rho_{i} \times C_{i} \times T_{i} / 10
$$

where SOCS and SNS $\left(\mathrm{Mg} \mathrm{ha}^{-1}\right)$ are soil organic carbon stock and soil nitrogen stock of a profile, respectively, $\theta_{i}$ is gravel (>2 $\mathrm{mm}$ ) content in horizon $\mathrm{i}(\%), \rho_{i}$ is soil bulk density in horizon i $\left(\mathrm{Mg} \mathrm{m}^{-3}\right)$, $\mathrm{C}_{\mathrm{i}}$ is concentration of organic carbon or nitrogen in horizon $\mathrm{i}\left(\mathrm{g} \mathrm{kg}^{-1}\right), \mathrm{T}_{\mathrm{i}}$ is the thickness of horizon $\mathrm{i}$ $(\mathrm{cm})$, and $\mathrm{n}$ is the numbers of horizons involved.

Statistical analyses: Data were examined using the Kolmogorov-Smirnov test for normality and the Levene test for homogeneity of variance. These statistical analyses were followed by one-way 
ANOVAs (F-test) and unequal N Tukey HSD, posthoc tests for the identification of significant differences among treatments. Statistical analyses were carried out using STATISTICA V.8.0 (StatSoft, 2008).

\section{RESULTS AND DISCUSSION}

The SOCS varied between $18.8 \mathrm{Mg} \mathrm{ha}^{-1}$ (i.e. crop field) and $88.7 \mathrm{Mg} \mathrm{ha}^{-1}$ (i.e. rangeland), mean 57.2 $\mathrm{Mg} \mathrm{ha}^{-1}$ (Table 1). The range of SOCS in the study area roughly corresponds to that in other surveys, although some of the values we measured were relatively low (Table 1). For example $\mathrm{Yu}$ et al. (2007) reported SOCS ranged 29-167.5 Mg ha ${ }^{-1}$ in different ecosystems in china (i.e. in forestland 143.3 $\mathrm{Mg} \mathrm{ha}^{-1}$, in farmland $92.2 \mathrm{Mg} \mathrm{ha}^{-1}$ and in desert land $\left.29 \mathrm{Mg} \mathrm{ha}^{-1}\right)$. Comparatively, the mean SOCS for forestland $\left(66.8 \mathrm{Mg} \mathrm{ha}^{-1}\right)$ found in the present study differs greatly from those found in that study. The
SOC stock was highest for forest land use sites for 0 $30 \mathrm{~cm}$ soil layers $(\mathrm{P}<0.01$; Fig. 2$)$, which showed the important contribution of soil organic towards enhancing SOC stock. Also a study in Laos showed that the highest organic carbon was stored in natural forests (Hett et al, 2011). The SOC stock was significantly different between three land use types (Table 1, Fig. 2). The mean SOC stock for $0-30 \mathrm{~cm}$ soil layer under different land uses varied in order forest $\left(66.9 \mathrm{Mg} \mathrm{ha}^{-1}\right)>$ rangeland $\left(63.3 \mathrm{Mg} \mathrm{ha}^{-1}\right)$ $>$ crop field (47.2 $\mathrm{Mg} \mathrm{ha}^{-1} ; P<0.01$ ) (Table $2 \&$ Fig. 2). Also other studies have shown the reduction of soil organic carbon stock in agricultural land due to human activity. For example, Krogh et al. (2003) in a study in Denmark showed that the SOCS in agricultural land is lower than the wetland and forest. Liu et al. (2011) were expressed in a study in China that human activity affects the amount of SOCS.

Table 1. Descriptive statistics of SOCS \& SNS in different land use types

\begin{tabular}{lllll}
\hline \multirow{2}{*}{ Land use } & \multirow{2}{*}{$\begin{array}{l}\text { No. of } \\
\text { samples }\end{array}$} & \multicolumn{3}{c}{ SOCS $\left(\mathrm{Mg} \mathrm{ha}^{-1}\right)$} \\
\cline { 3 - 5 } Total & 39 & 57.2 & 16.4 & 2.6 \\
Crop field & 17 & 47.1 & 14.3 & 3.5 \\
Rangeland & 12 & 63.3 & 17.2 & 5.0 \\
Forest & 10 & 66.8 & 7.8 & 2.5 \\
\hline \multirow{2}{*}{ Land use } & No. of & & SNS $\left(\mathrm{Mg} \mathrm{ha}^{-1}\right)$ \\
\cline { 3 - 5 } & samples & Mean & S.D. & S.E. \\
\hline Total & 39 & 9.3 & 3.44 & 0.55 \\
Crop field & 17 & 6.98 & 2.61 & 0.63 \\
Rangeland & 12 & 10.83 & 3.1 & 0.89 \\
Forest & 10 & 11.5 & 2.72 & 0.86 \\
\hline
\end{tabular}

Table 2. One way ANOVA for the effects of land use types on SOCS and SNS

\begin{tabular}{llllll}
\hline Effect & d.f. & \multicolumn{1}{c}{ SS } & \multicolumn{1}{c}{ MS } & \multicolumn{1}{c}{ F } & \multicolumn{1}{c}{ p } \\
\hline SOCS & & & & & \\
Intercept & 1 & 129848 & 129848 & 660 & $<0.0001$ \\
Land use & 2 & 3098 & 1549 & 8 & 0.001 \\
Error & 36 & 7087 & 197 & & \\
Total & 38 & 10185 & & & \\
\hline SNS & & & & & \\
Intercept & 1 & 3547.66 & 3547.66 & 455 & $<0.0001$ \\
Land use & 2 & 168.21 & 84.1 & 10.79 & 0.001 \\
Error & 36 & 280.67 & 7.8 & & \\
Total & 38 & 448.88 & & & \\
\hline
\end{tabular}




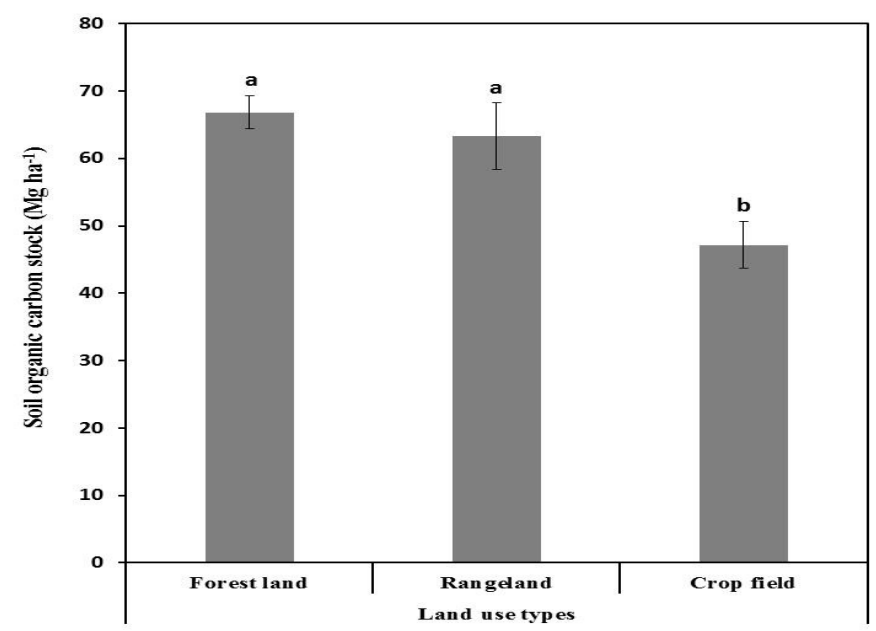

Fig. 2 Soil organic carbon (SOC) stock in different land unit under surface erosion. Different letters indicate that SOC stock is significantly different at $1 \%$ level based on Tukey HSD Post-hoc test.

Berhe et al. (2007) estimated that the annual erosioninduced $\mathrm{C}$ sink offset global fossil fuel emissions of $\mathrm{CO}_{2}$ by up to $10 \%$ in 2005 . Van Oost et al. (2007) point to an erosion-induced sink of atmospheric C equivalent to approximately $26 \%$ of the $\mathrm{C}$ transported by erosion. In semi-arid climates, Haregeweyn et al. (2008) underlined the potential of reservoirs to act as important stores of organic $\mathrm{C}$ in the global $\mathrm{C}$ balance. At a much larger scale and climatic conditions varying from semi-arid to humid in different sub-catchments, Smith et al. (2005) concluded that soil erosion results in a net sink of atmospheric $\mathrm{CO}_{2}$. Results also differ concerning erosion mechanisms that lead to different amounts and types of mobilized soil organic C. About $75 \%$ of total terrestrial $\mathrm{C}$ is stored in the world's soils (Henderson, 1995), and forest soils hold about $40 \%$ of all belowground C (Dixon et al., 1994). Therefore, even if surface soil erosion only slightly affects soil $\mathrm{C}$ stocks at catchment scale, it could have a significant effect on the global $\mathrm{C}$ budget.

The mean of SNS in the study area is $9.3 \mathrm{Mg}$ ha- 1 . Our results indicated that land use had significantly impacted SNS $(\mathrm{p}<0.01)$. As shown in Table 1 and Fig. 3, the mean SNS values for the three land-usebased groups were significantly different $(p<0.01)$, being highest for forest land (11.5 Mg ha-1), intermediate for rangeland (10.83 Mg ha-1) and lowest for crop field (9.98 Mg ha-1).

Fig. 4 shows the amount of organic carbon stock in the basin compared with other studies in other parts of the world. This comparison shows a lower SOCS in the study area compared to the other regions.

Top soil layer is affected by soil erosion process and land management practices, directly. Therefore, it will be sensitive to environment changes and land use. It seems unlikely that future changes in rangelands including land degradation could compensate for this SOC and TN loss in rangeland soils in the semi-arid area.

\section{CONCLUSION}

Organic carbon and nitrogen stocks are highly variable at a catchment scale. This study showed that at catchment scale forest land stored more carbon and nitrogen than rangeland and crop field. These differences can most probably be accounted for by vegetation percent cover. Our results can also help understand the major biogeochemical cycles that influence soil fertility and help devise management strategies that enhance the sustainability of these areas and thus slow further deforestation. Thus, slight reductions in SOC contents due to changes in landuse, soil management, or rates of soil erosion, could significantly raise the $\mathrm{CO}_{2}$ concentration in the atmosphere. These results only present the current SOCS in different land use types affected by soil erosion across a semi-arid catchment in Iran. It is possible that appropriate management practices such as fertilization, soil erosion control and would enhance SOC sequestration in the study area.

Acknowledgements: This project was funded by a grant from the research council of Shahid Beheshti University, Tehran, Iran. 


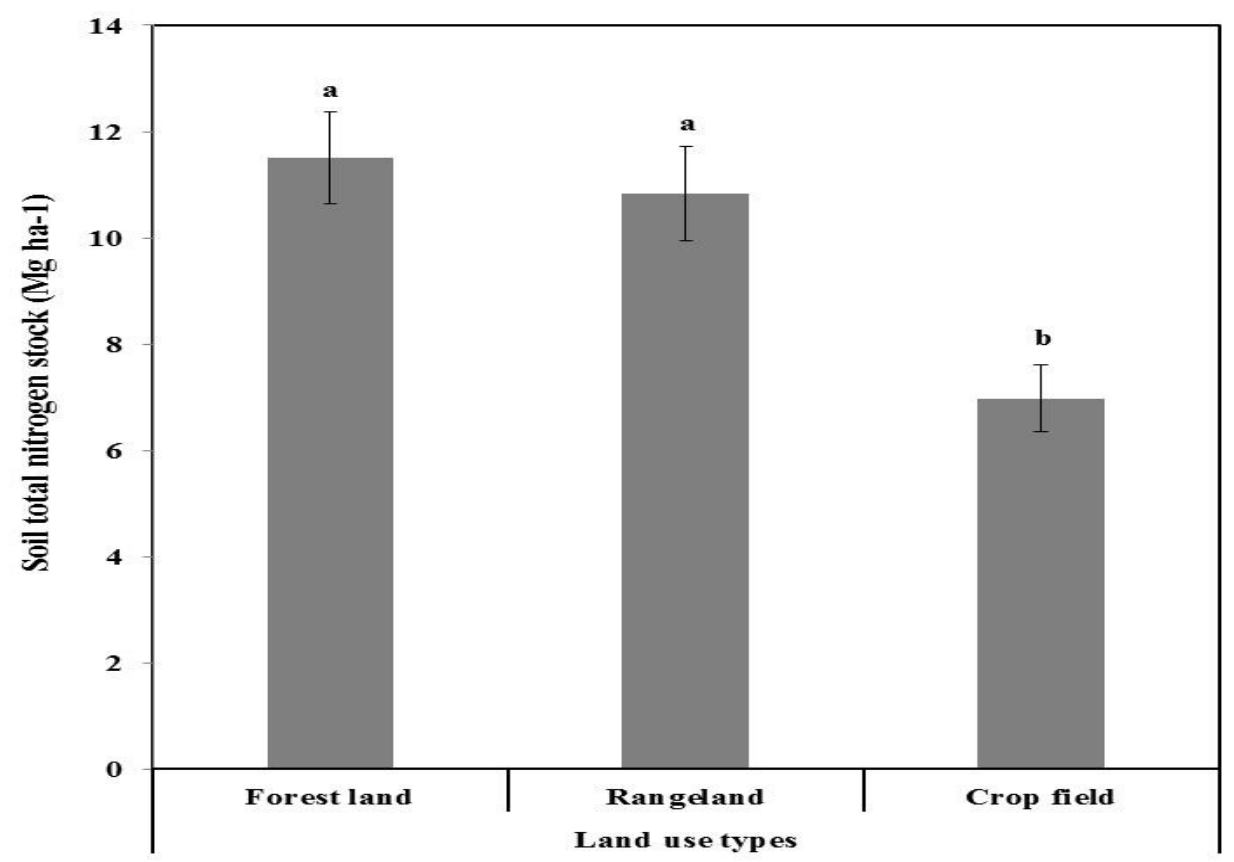

Fig. 3 Soil nitrogen (SN) stock in different land unit under surface erosion.

Different letters indicate that SN stock is significantly different at $1 \%$ level based on Tukey HSD Post-hoc test.

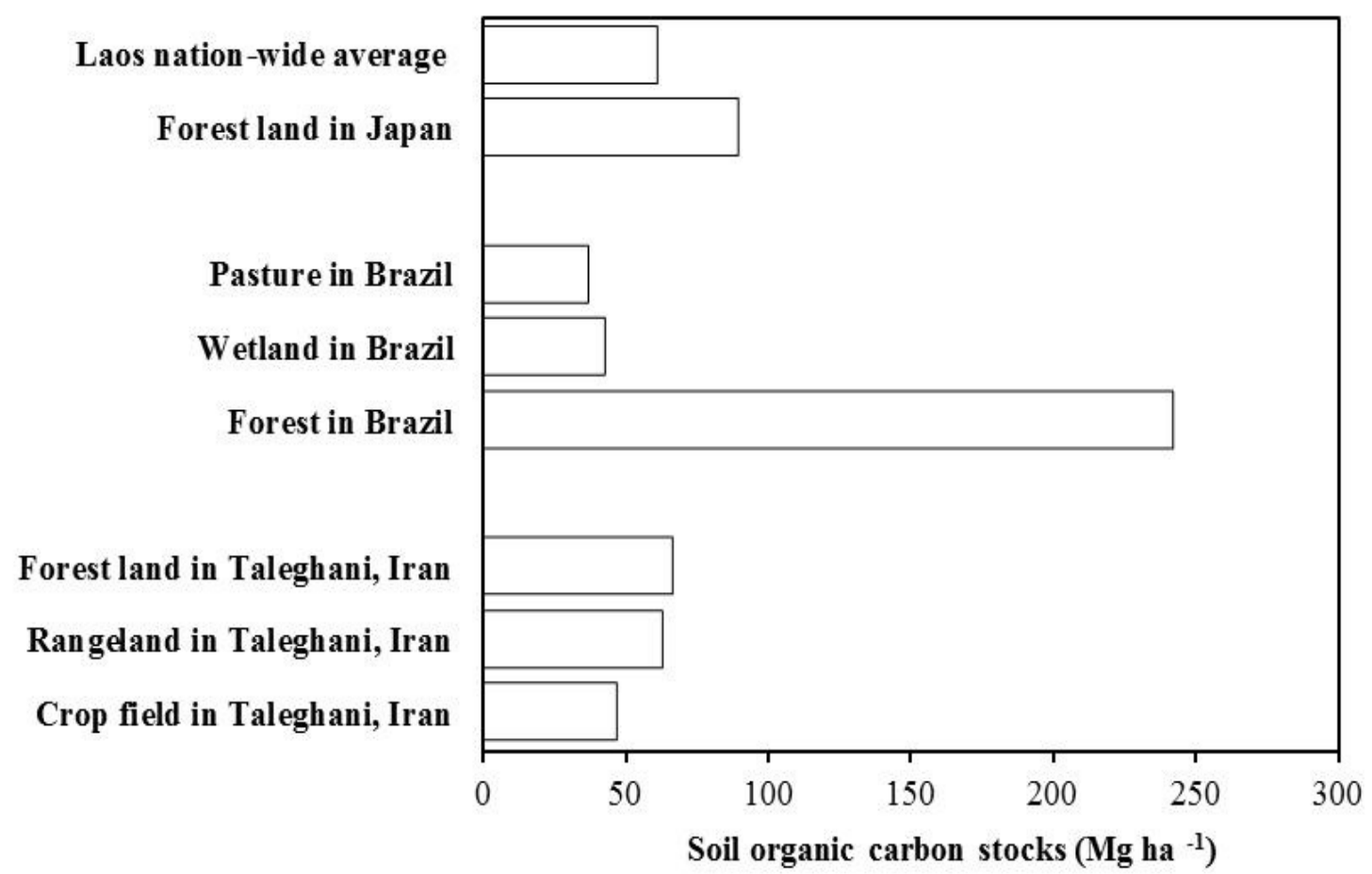

Fig. 4 Comparison of soil organic carbon in the study area in a depth of $30 \mathrm{~cm}$ with some studies of global and regional based on their data (Hett et al, 2011; Morisada et al, 2004; Wantzen et al, 2012).

\section{REFERENCES}

Berhe A A, Harte J, Harden J W, Torn M S. 2007.

The significance of the erosion-induced terrestrial carbon sink. Bioscience 57(4): $337-$ 346. 
Blake G R, Hartge K H. 1986. Bulk density In: Klute, A. (Ed.), Methods of Soil Analysis. I. ASA Monograph No. 9. Madison, WI, pp. 363376.

Blanco-Canqui H, Lal R. 2008. Principles of Soil Conservation: Springer Verlag.

Dixon R K, Brown S, Houghton R A, Solomon A M, Trexler M C, Wisniewski J. 1994. Carbon pools and flux of global forest ecosystems. Science 263, 185-190.

Don A, Schumacher J, Scherer-Lorenzen M, Scholten T, Schulze E-D. 2007. Spatial and vertical variation of soil carbon at two grassland sites - Implications for measuring soil carbon stocks. Geoderma 141(3-4): 272-282.

Grimm R, Behrens T, Märker M, Elsenbeer H. 2008. Soil organic carbon concentrations and stocks on Barro Colorado Island - Digital soil mapping using Random Forests analysis. Geoderma 146(1-2): 102-113.

Haregeweyn N, Poesen J, Deckers J, Nyssen J, Haile M, Govers G, Verstraeten G, Moeyersons J. 2008. Sediment-bound nutrient export from micro-dam catchments in Northern Ethiopia. Land Degradation \& Development 19(2): 136152.

Henderson G S. 1995. Soil organic matter: a link between forest management and productivity. In: Bigham J M, Bartels J M. (Eds.), Carbon Forms and Functions in Forest Soils. Soils Science Society of America, Madison, WI, pp. 419-435.

Hett C, Heinimann A, Messerli P. 2011. Spatial assessment of carbon stocks of living vegetation at the national level in Lao PDR. Geografisk TidsskriftDanish Journal of Geography 111(1): 11.

John B, Yamashita T, Ludwig B, Flessa H. 2005. Storage of organic carbon in aggregate and density fractions of silty soils under different types of land use. Geoderma 128(1-2): 63-79.

Krogh L, Noergaard A, Hermansen M, Greve M H, Balstroem T, Breuning-Madsen H. 2003. Preliminary estimates of contemporary soil organic carbon stocks in Denmark using multiple datasets and four scalingup methods. Agriculture, ecosystems \& environment 96(1-3): 19-28.
Lal R. 2003. Soil erosion and the global carbon budget. Environment International 29(4): 437-450.

Lal R, Griffin M, Apt J, Lave L, Morgan M G. (2004): Managing Soil Carbon. Science, 304: 393.

Leifeld J, Bassin S, Fuhrer J. 2005. Carbon stocks in Swiss agricultural soils predicted by land-use, soil characteristics, and altitude. Agriculture, Ecosystems \& Environment 105(1-2): 255-266.

Liu Z, Shao M, Wang Y. 2011. Effect of environmental factors on regional soil organic carbon stocks across the Loess Plateau region, China. Agriculture, Ecosystems \& Environment 142(3-4):184-194.

Morisada K, Ono K, Kanomata H. 2004. Organic carbon stock in forest soils in Japan. Geoderma 119(1): 2132 .

Rutherford P M, McGill W B, Arocena J M, Figueiredo C T. 2008. Total nitrogen. In: Carter M R, Gregorich $E$ G. (Eds.), Soil Sampling and Methods of Analysis 2 ed. (pp. 239-250): Boca Raton: CRC Press.

Skjemstad J O, Baldock J A. 2008. Total and organic carbon. In: Carter M R, Gregorich E G. (Eds.), Soil Sampling and Methods of Analysis 2 ed. (pp. 225237): Boca Raton: CRC Press.

Smith S V, Sleezer R, Renwick W, Buddemeier R. 2005. Fates of eroded soil organic carbon: Mississippi basin case study. Ecological Applications 15(6): 1929-1940.

StatSoft. 2008. STATISTICA: [data analysis software system], Version 8.0 for Windows update. StatSoft, Inc. In 8.0 for Windows update ed.).

Van Oost K, Quine T, Govers G, De Gryze S, Six J, Harden J, Ritchie J, McCarty G, Heckrath G, Kosmas C. 2007. The impact of agricultural soil erosion on the global carbon cycle. Science 318(5850): 626-629.

Wang Y, Fu B, Lü Y, Song C, Luan Y. 2010. Local-scale spatial variability of soil organic carbon and its stock in the hilly area of the Loess Plateau, China. Quaternary Research 73(1): 70-76.

Wantzen K M, Couto E G, Mund E E, Amorim R S S, Siqueira A, Tielbörger K, Seifan M. 2012. Soil carbon stocks in stream-valley-ecosystems in the Brazilian Cerrado agroscape. Agriculture, Ecosystems \& Environment 151, 70-79.

Yu D S, Shi X Z, Wang H J, Sun W X, Chen J M, Liu Q H, Zhao Y C. 2007. Regional patterns of soil organic carbon stocks in China. Journal of Environmental Management 85(3): 680-689. 